\title{
Does School Organizational Process Matter for Educational Outcomes in England?
}

\begin{abstract}
Amira Elasra
The Department of Economics, Faculty of Social Sciences building, University of Warwick, England

\begin{tabular}{ll}
\hline & ABSTRACT \\
\cline { 2 - 3 } $\begin{array}{l}\text { Keywords: } \\
\text { Educational Outcomes, School } \\
\text { Organizational Process, } \\
\text { Teacher Quality, School }\end{array}$ & $\begin{array}{l}\text { Mardly of the existing literature have shown that the educational production function approach } \\
\text { teacher and school organizational effectiveness impacts on English students' both cognitive } \\
\text { and affective outcomes using the Context-Input-Process-Outcome model. Using the }\end{array}$ \\
& $\begin{array}{l}\text { Longitudinal Study of Young People in England, the primary finding is that teachers matter. } \\
\text { Teachers play a significant positive moderate role in improving students' cognitive outcome }\end{array}$ \\
Received & yet a much bigger role in improving their affective outcome. Although the paper proved that \\
Received in revised form & school organizational process inputs are important in explaining students' outcomes, the \\
26 October 2020 & moderate magnitude of some of these inputs on cognitive outcome reflected that student- \\
Accepted & related inputs such as academic self-schema and attitude towards continuing to higher \\
education could play a major role in explaining such outcome.
\end{tabular}
\end{abstract}

27 October 2020

*Correspondence:

A.Elasra@warwick.ac.uk

CCIKD Publishing

\section{Introduction and Motivation}

Despite the expansion of the literature on the implications different inputs have on students' educational outcomes, empirical research has so far lacked, in some instances, the full capacity to provide unequivocal findings. Essentially, this deficiency is mainly attributed to two main factors; the lack of reliable data and the lack of full dimensionality in the theoretical model adopted to explain such data (Knoeppel, Verstegen, \& Rinehart, 2007; Kyriakides, 2005; Levaččićć \& Vignoles, 2002; Rivkin, Hanushek, \& Kain, 2005).

The theoretical model adopted to explain the data plays a major role in reaching unambiguous findings. On one side, education specialists rely on what is known as school effectiveness analysis, while on the other side economists rely on more quantitative analysis under the general framework of educational production functions, also known as input-output or cost-quality analyses (Levaččićć \& Vignoles, 2002; Knoeppel, Verstegen, \& Rinehart, 2007; Kyriakides, 2005). 
The theoretical model mostly used is known as the 'Context-Input-Process-Outcome' model (Teddlie \& Reynolds, 2000); hereafter CIPO model. The idea and advantage of the model is to incorporate all the possible inputs that affect students' outputs. Education specialists adopt the school effectiveness approach focusing mainly on the school organizational process component unlike economists who adopt the educational production function approach focusing on resources inputs (Kyriakides, 2005; Levaččićć \& Vignoles, 2002). This leads to methodological limitations. A typical educational production function can be represented by equation (1) (Levaččićć \& Vignoles, 2002)

$$
O_{h i j}=f\left(Z_{1 h i j}, \ldots, Z_{M h i j}\right)
$$

where $O_{h i j}$ are $H$ educational outcomes of student $i$ at school $j$ and $Z_{M h i j}$ are $M$ inputs allocated to the production of these outcomes including school resources, school context inputs and students' inputs.

This paper identifies a number of gaps in the Education Economics literature. First, most of the existing literature have shown that the educational production function approach hardly accounts for the school organizational process variables (Armor et al., 1976; Glewwe et al., 2011; Kerckhoff, 1986; Levaččićć \& Vignoles, 2002; Murnane, 1975; Teddlie \& Reynolds, 2000). Second, previous research has examined both school effectiveness and teacher effectiveness separately (Kyriakides, 2005; Teddlie, 1994). Third, there is a lack of studies examining both cognitive and non-cognitive outcomes (Sammons, Hillman, \& Mortimore, 1995; Teddlie \& Reynolds, 2000) with exceptions of Mortimore, et al. (1988), Rutter (1979), Knuver and Brandsma, 1993, and Kyriakides, 2005. Last, most of the earlier research has generally been less focused on the case of England (Kerckhoff, 1986; Levaččićć \& Vignoles, 2002; Sammons, et al., 1995; Slater, Davies, \& Burgess, 2009; Tymms, 1992).

This paper answers four research questions: What is the teacher influence on student's cognitive and affective outcomes? Which aspect of school quality in the school organizational process component is more predictive of student's cognitive and affective outcomes? What is the effect of overall school quality on student's cognitive and affective outcomes? How important is the school process component in the CIPO model? And whether other factors are more important in explaining student's outcomes?

In order to answer these questions, the paper examines the effect of school organizational process variables on students' both cognitive and affective educational outcomes using a more comprehensive theoretical framework based on the Context-Input-Process-Outcome model. Particularly, the analysis adjusts equation (1) to (2) by studying the effect of $K$ school process variables; $P_{K i j}$ on the student level outcome rather than the school level, where $C_{L i j}$ are $L$ school context variables for student $i$ at school $j$ and $X_{N i j}$ are $N$ student input variables.

$$
O_{h i}=f\left(P_{1 i j} \ldots P_{K i j}, C_{1 i} \ldots C_{L i}, X_{1 i} \ldots X_{N i}\right)
$$

Additionally, the paper combines both the teacher and school effectiveness by examining the school process inputs at both the school level and the teacher level that are not financial resource oriented inputs. In short, the analysis combines teacher's influence variable measuring student's perception of their teacher and school quality variable(s), to examine their effect simultaneously on students' educational outcomes.

The analysis of the paper is based on a dataset built comprising data from the Longitudinal study of Young People in England (LSYPE), the National Pupil Database (NPD) and the Ofsted database, 
hence including new school information that have been lacked in the literature covering a wide range of school process variables in the analysis. The paper proceeds with a review of empirical literature of the effect of school process inputs on educational outcomes followed by data, statistical method and model specification, main findings, conclusion, and discussion.

\section{Review of Empirical Literature}

Following the findings of Coleman's report (1966) that there is no strong positive relationship between school financial resources and students' outcomes, several studies were conducted to further investigate the effect of school inputs on students' outcomes (Mortimore, 1993; Mortimore et al., 1988; Reynolds \& Creemers, 1990; Sammons, Hillman, \& Mortimore, 1995).

During the last three decades, a considerable body of research evidence has been accumulated showing that although family backgrounds of students and their academic self-schema are major determinants of their educational outcomes, schools have significant though small contribution in explaining variations in students' outcomes (Daly, 1991; Mortimore et al., 1988; Reynolds, 1982; Rutter, 1979; Sammons, Hillman, \& Mortimore, 1995; Wilkins \& Raudenbush, 1989). For example, student sense of control of their environment, quality of teachers' education, and teachers' high expectations for students are types of school process factors that tend to have significant positive relationships with students' outcomes (Link \& Ratledge, 1979; Summers \& Wolfe, 1977; Winkler, 1975). The following review focuses on key empirical studies examining the effects of school process inputs, specifically school quality inputs and teacher inputs on student's educational outcomes.

\section{School Organizational Process Inputs: School Level (Quality)}

Most researchers who examined the effect of school organizational process variables focused on urban elementary schools with low socioeconomic status because they believed that success stories of these schools would dispel the belief that schools made little or no difference (Teddlie \& Reynolds, 2000). Some show that Leadership, expectations, school atmosphere, evaluation of pupil progress (Weber, 1971) and principals' evaluations of teachers (Murnane, 1975) are important (Armor et al., 1976; Teddlie \& Reynolds, 2000).

School effectiveness literature has examined a wide range of school organizational process factors (Sammons, Hillman, \& Mortimore, 1995). These include professional leadership (Mortimore et al., 1988; Rutter, 1979), shared visions and goals (Mortimore et al. 1988), a learning environment (Rutter, 1979; Weber, 1971), concentration on teaching and learning (Mortimore, 1993), purposeful teaching (Mortimore, 1993; Rutter, 1979; Stalling, 1975), high expectations (Edmonds, 1979; Rutter, 1979), positive reinforcement (Walberg, 1984), monitoring progress (Edmonds, 1979; Weber, 1971), pupil rights and responsibilities (Mortimore et al., 1988), homeschool partnership (Mortimore et al., 1988) and a learning organization (Armor et al., 1976).

Most studies tend to focus on the effect of one or more of these variables on students' educational outcomes. For example, faculty cooperation and cohesion in general and teaching staff cooperation in relation to teaching methods and pupil counselling in particular are seen as key components of a productive school climate and culture that have positive impact on students' cognitive and affective outcomes (Anderson, 1982; Opdenakker \& Van Damme, 2000; Sammons, Hillman, \& Mortimore, 1995). On the other hand, some school process variables tend to have 
mixed effect such as attention to pupil differences and development (Opdenakker \& Van Damme, 2000; Scheerens \& Creemers, 1996).

Empirical support for the effectiveness of an orderly learning environment in the school has been confirmed (Opdenakker \& Van Damme, 2000). Similarly, 'focus on discipline and subject matter acquisition' and 'focus on cultural education and creativity' though not much studied, were found to have only significant positive effect on affective outcomes of students with initial high cognitive and affective characteristics and negative effect for students with initial low cognitive and affective characteristics (Opdenakker \& Van Damme, 2000). Also, the 'focus on education and personality development' has a positive effect on the motivation towards (and interest in) learning tasks. On the other hand, it had a differential effect on the attitude towards homework. Additionally, it was suggested to have a negative effect on mathematics cognitive outcomes (Opdenakker \& Van Damme, 2000).

Decentralization and giving more autonomy to school management enhances students' outcomes (Faguet \& Sanchez, 2008; PISA, 2009; Woessmann, 2003) and attendance and probability to continue schooling (Jimenez \& Sawada, 1999, 2003), though better-off communities tend to benefit more from such policy (Galiani, Gertler, \& Schargrodsky, 2008; Galiani \& PerezTruglia, 2011). However, few studies suggested that decentralization increased the drop-out rates and failure rates among primary school students in Brazil even if it increased enrollment levels (Madeira, 2012) 'Rules and agreements about aspects of classroom instruction', 'rules and agreements about ways of improving affective outcomes', and 'assessment system focused on formative purposes' (also at the head teacher level) were found to be significant predictors of students' outcomes. On the other hand, 'rules about time use' and 'consensus about the "mission" of the school' were not significant for cognitive outcomes, while the latter was only significant for affective outcomes (Kyriakides, 2005).

\section{School Organizational Process Inputs: Teacher Level}

Previous empirical research has shown that in general teachers may not have a strong role in determining students' achievement mainly because of lacking consensus on the exact link between observable teacher characteristics and such achievement (Rivkin, Hanushek, \& Kain, 2005). Teacher experience and education demonstrated no consistent effect on student achievement (Hanushek, 1971, 1981, 1986; Hedges, Laine, \& Greenwald, 1994a; Rivkin, Hanushek, \& Kain, 2005). On one hand, some researchers suggested a weak relationship between teacher experience and students' test scores (Hanushek \& Luque, 2003).

The quality of teacher's education has also been debated. On one hand, some researchers proposed a positive impact on student's outcomes (Summers \& Wolfe, 1977). However, a review of Hanushek's studies showed that only $7 \%$ of them found a positive significant relationship between teacher's education and students' outcomes (Hedges, Laine, \& Greenwald, 1994a).

Teachers' absence has a negative impact on students' test scores in Zambia (Das et al., 2007). Teachers' wages have a statistically significant positive impact on students' attainment in Brazil (Menezes-Filho \& Pazello, 2007). Equally, teacher training has a positive impact on elementary schools students' achievements in Jerusalem and that it was more cost effective than reducing class size or lengthening school day (Angrist \& Lavy, 2001). Similarly, lengthening the instruction time in public schools in Chile has a positive significant effect on students' achievement with a larger effect in rural areas (Bellei, 2009).

Studying teacher's effect on student's educational outcome from a school process perspective has shown that earlier emphasis on more traditional teacher characteristics such as teacher's years of education or experience may have been misplaced. For example, it was indicated that there is a 
large positive relationship between outcome and student's perception of a positive teacher's attitude towards him/herself. Such influence was coupled with no significant impact of teacher education or experience (Link \& Ratledge, 1979).

In a similar framework, the effect of teachers on students' outcomes was also examined in terms of how effective the teacher is with respect to student's perception of the teaching quality, the time spent on tasks in the classroom and the opportunity to learn with the homework assigned. One of the studies that followed that framework showed that teaching quality variables were significant predictors of students' cognitive and affective outcomes. Also, teacher practices were significant predictors of students' cognitive outcome, while time spent on teaching was not significant for such outcome (Kyriakides, 2005).

Teacher quality was found to have a positive impact on student's cognitive outcomes in the USA (Rivkin, Hanushek, \& Kain, 2005). Moreover, little of the variation in teacher quality was explained by observable characteristic, such as education or experience. Similar findings were reported in England (Slater, Davies, \& Burgess, 2009). Specifically, teacher quality makes a big difference in the outcome of students and can reduce the socio-economic gap between students' GCSE outcomes.

\section{Method}

The data is an integrated dataset of the LSYPE, the NPD and the Ofsted. The student's cognitive outcome is measured by their key stage 4 (KS4) total GCSE/GNVQ new style point score for the year 2005/2006 using a sample of 1664 students in 187 schools and measures the student's affective outcome by their average score of attitude towards school given by the answers to five questions, where for each question the student can answer one of 5 categories: 'strongly disagree', 'disagree', 'I don't know', 'agree' and 'strongly agree' using a sample of 1520 students in 183 schools.

\section{Independent Variables}

The analysis examines two key school process variables; teacher influence variable and school quality variable. This paper uses student's perception of their teacher to measure teacher influence. Specifically, three variables were constructed based on data from the LSYPE; student-teacher relationship $\left(\alpha^{1}=.21\right)$, teacher quality $(\alpha=.82)$ and overall teacher index $(\alpha=.71)$. The Ofsted database provides information about school performance for the year 2005/2006 ${ }^{2}$ using nine key judgements covering 56 questions. Nine indices were constructed for the nine judgements reflecting school overall effectiveness (OE, $\alpha=.80$ ), achievement and standards (AS, $\alpha=.86$ ), personal development and well-being (PDW, $\alpha=.94$ ), the quality of provision (QP, $\alpha=.81$ ), leadership and management (LM, $\alpha=.89)$, the extent to which schools enable learners to be healthy (ESELH, $\alpha=-.56$ ), the extent to which providers ensure that learners stay safe (EPELS, $\alpha=-1.35$ ), the extent to which learners make a positive contribution (ELMPC, $\alpha=.80$ ) and the extent to which schools enable learners to achieve economic well-being (ESELEW, $\alpha=.22$ ). An overall school quality index was also constructed to measure the overall school performance using the above nine indices and to overcome the internal inconsistency of the three inconsistent indices $(\alpha=.96)$.

Given the nature of the variables used to construct the previous nine school quality indices, it could be argued that only the AS and PDW indices could suffer from a possible endogeneity

\footnotetext{
${ }^{1}$ Cronbach's alpha (Cronbach, 1951).

2 The Ofsted inspection was conducted between September 2005 and July 2006.
} 
problem with the KS4 outcome variable, where they were more or less measured around similar time point. However, a counter argument suggests that the number of students per school in the sample is very small.

\section{Econometric Method and Model specification}

The cognitive outcome variable is a count variable that follows a negative binomial distribution, hence is examined by a negative binomial regression model. While, the affective outcome variable is an ordinal variable examined by an ordinal logit model. The analysis starts by examining the teacher's effect on school cognitive outcome model (eq. 3), via three main specifications, each examining one of the three previously constructed teacher indices.

$$
\ln \left(\mu(c o)_{i t}\right)=\alpha+\gamma T_{i, t-1, t-2}+\sum_{L} \zeta_{L}\left(C_{i t}+C_{i, t-2}\right)+\sum_{N} \beta_{N}\left(X_{i, t-1}+X_{i, t-2}\right)+\varepsilon_{i}
$$

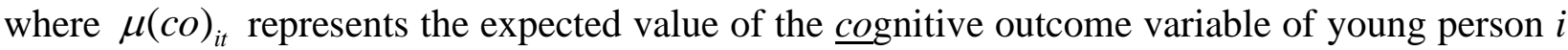
measured at time $t$ corresponding to year 2005/2006 when the KS4 outcome was measured (around wave three), $T_{i, t-1, t-2}$ is the teacher influence index measured via three different indices (each constructed by a mix of variables measured at both wave one $(t-2)$ and wave two $(t-1)), C_{L i}(L=2)$ are the school context variables; one representing the school phase of education at time $t$ and the other representing a dummy for whether the school attended at wave one $(t-2)$ was an independent or maintained school, and $X_{N i}(N=17)$ are student's input variables measured at either wave one $(t-2)$ or wave two (t-1). The same model is examined for the affective outcome (eq. 4$)$, where $\mu(a f)_{i, t+1}$ represents the expected value of the affective outcome variable of young person $i$ measured at time $(t+1)$ corresponding to wave four when the outcome was measured.

$$
\ln \left(\mu(a f)_{i, t+1} / 1-\mu(a f)_{i, t+1}\right)=\alpha+\gamma T_{i, t-1, t-2}+\sum_{L} \zeta_{L}\left(C_{i t}+C_{i, t-2}\right)+\sum_{N} \beta_{N}\left(X_{i, t-1}+X_{i, t-2}\right)+\varepsilon_{i}
$$

The analysis then examines the full model after adding the school quality effect measured at year 2005/2006 (eq. 5 examining the cognitive outcome and eq. 6 examining the effective outcome). Specifically, the model was examined via ten specifications each examining one of the ten school quality indices $(S Q)$ explained earlier.

$$
\begin{gathered}
\ln \left(\mu(c o)_{i t}\right)=\alpha+\gamma T_{i, t-1, t-2}+\lambda S Q_{i j t}+\sum_{L} \zeta_{L}\left(C_{i t}+C_{i, t-2}\right)+\sum_{N} \beta_{N}\left(X_{i, t-1}+X_{i, t-2}\right)+\varepsilon_{i} \\
\ln \left(\mu(a f)_{i, t+1} / 1-\mu(a f)_{i, t+1}\right)=\alpha+\gamma T_{i, t-1, t-2}+\lambda S Q_{i j t}+\sum_{L} \zeta_{L}\left(C_{i t}+C_{i, t-2}\right)+ \\
\sum_{N} \beta_{N}\left(X_{i, t-1}+X_{i, t-2}\right)+\varepsilon_{i}
\end{gathered}
$$

where $S Q_{i j t}$ represents the school quality index for young person $i$ at school $j$ at time $t$.

\section{Findings}

\section{Students' Cognitive Outcome}

Table 1 shows that the student-teacher relationship index, model (1), is not a significant predictor and that the other two teacher indices could be better predictors. The teacher quality index however shows that with each 1 standard deviation increase in teacher quality the expected value of KS4 score goes up by $6.3 \%$. Also, the overall teacher index is significantly positive with a similar size 6\%. These findings support those of Aaronson, Barrow and Sander (2007), Glewwe et al., (2011), Kyriakides (2005), Link and Ratledge (1979) and Rivkin, Hanushek and Kain (2005) even though 
such influence is relatively small in size indicating that student's inputs may play a bigger role in explaining their cognitive outcome.

Table 1

Teacher Influence on Cognitive Outcome

\begin{tabular}{|c|c|c|c|}
\hline VARIABLES & $\begin{array}{l}\text { (1) } \\
\text { IRR }\end{array}$ & $\begin{array}{l}\text { (2) } \\
\text { IRR }\end{array}$ & $\begin{array}{l}\text { (3) } \\
\text { IRR }\end{array}$ \\
\hline \multicolumn{4}{|l|}{ Teacher Influence } \\
\hline Student/teacher relation index & $\begin{array}{l}1.003 \\
(.002)\end{array}$ & & \\
\hline Teacher quality index & & $\begin{array}{l}1.007 * * * \\
(.001)\end{array}$ & \\
\hline Overall teacher index & & & $\begin{array}{l}1.005^{* * * *} \\
(.001)\end{array}$ \\
\hline \multicolumn{4}{|l|}{ Student Inputs } \\
\hline KS3 score $(\mathrm{Z})$ & $\begin{array}{l}1.39 * * * \\
(.03)\end{array}$ & $\begin{array}{l}1.38 * * * \\
(.03)\end{array}$ & $\begin{array}{l}1.392^{* * * *} \\
(.03)\end{array}$ \\
\hline \multicolumn{4}{|c|}{$\begin{array}{l}\text { Likelihood of the young person applying to university } \\
\text { (reference level: not at all likely) }\end{array}$} \\
\hline Not very likely & $\begin{array}{l}1.16^{* * *} \\
(.06)\end{array}$ & $\begin{array}{l}1.15^{* *} \\
(.06)\end{array}$ & $\begin{array}{l}1.148^{* *} \\
(.06)\end{array}$ \\
\hline Fairly likely & $\begin{array}{l}1.23 * * * \\
(.06)\end{array}$ & $\begin{array}{l}1.21 * * * \\
(.06)\end{array}$ & $\begin{array}{l}1.21 * * * \\
(.06)\end{array}$ \\
\hline Very likely & $\begin{array}{l}1.22 * * * \\
(.06)\end{array}$ & $\begin{array}{l}1.19 * * * \\
(.06)\end{array}$ & $\begin{array}{l}1.18 * * * \\
(.06)\end{array}$ \\
\hline
\end{tabular}

Standard error (Eform) in parentheses. $* * * p<.001, * * p<.05, * p<.01$.

The models throughout the paper control for whether an independent school, school phase of education, highest qualification of family, family ns-sec class, mean income, IDACI score, type of household tenure, urban/rural indicator, how the young person's expenses would be paid if stayed on in education- parent(s) will support or give money, how involved is the MP in the young person's school life? whether or not there is internet access from home, whether or not there is home computer in the household, family structure, young person's religion, ethnicity, gender, young person has special educational needs and age.

The most important student's input in model (3) was their academic self-schema or prior attainment measured by KS3 score, which had a significant positive association with KS4 score, where one standard deviation increase in KS3 score was associated with $39.2 \%$ increase in the expected value of KS4 score (Duran \& Weffer, 1992; Glick \& Sahn, 2010; Tymms, 1992). Similar conclusion was found in an earlier UK study (Chowdry, Crawford, \& Goodman, 2011). Similarly, the likelihood of applying to university had also a positive significant association, where students who were very likely to apply to university were more likely to have higher expected value of KS4 score by almost $19 \%$ compared to those who were not likely at all to apply to university (Chowdry, Crawford, \& Goodman, 2009).

The model then introduces school quality effect as indicated in Table 2, where all school quality indices had a significant positive association with the student's outcome aside from the two indices reflecting the extent to which schools enable learners to be healthy (ESELH) and the extent to which learners make a positive contribution (ELMPC).

Despite the positive significant impact of most of the first nine school quality indices, the magnitude of such importance was relatively small ranging between almost $2 \%$ for one standard deviation increase in the extent to which providers ensure that learners stay safe index (EPELS) and $5.4 \%$ for the overall effectiveness index (OE). However, given that the former lacked sufficient internal consistency, it could be concluded that the latter (OE) is the most important aspect of school performance in explaining cognitive outcome. The last column in Table 2 examined the impact of the overall school quality index, which reflects all the previous nine indices. Despite the 
significant positive impact of the overall index, it as well had a small magnitude of only $6.2 \%$ on cognitive outcome.

Table 2

School Quality Effect on Cognitive Outcome

\begin{tabular}{|c|c|c|c|c|c|c|c|c|c|c|}
\hline & (1) & (2) & (3) & (4) & (5) & (6) & (7) & (8) & (9) & (10) \\
\hline VARIABLES & IRR & IRR & IRR & IRR & IRR & & & & & IRR \\
\hline \multicolumn{11}{|l|}{ School Process } \\
\hline SchOE_A & $\begin{array}{l}1.009 * * * \\
(.002)\end{array}$ & & & & & & & & & \\
\hline SchAS_A & & $\begin{array}{l}1.007 * * * * \\
(.002)\end{array}$ & & & & & & & & \\
\hline SchPDW_A & & & $\begin{array}{l}1.005^{* * * *} \\
(.001)\end{array}$ & & & & & & & \\
\hline SchQP_A & & & & $\begin{array}{l}1.01 * * * \\
(.003)\end{array}$ & & & & & & \\
\hline SchLM_A & & & & & $\begin{array}{l}1.007 * * * \\
(.002)\end{array}$ & & & & & \\
\hline SchESELH_A & & & & & & $\begin{array}{l}1.01 \\
(.006)\end{array}$ & & & & \\
\hline SchEPELS_A & & & & & & & $\begin{array}{l}1.02^{* * * *} \\
(.004)\end{array}$ & & & \\
\hline SchELMPC_A & & & & & & & & $\begin{array}{l}1.007 \\
(.005)\end{array}$ & & \\
\hline SchESELEW_A & & & & & & & & & $\begin{array}{l}1.01 * * \\
(.006)\end{array}$ & \\
\hline Overall school quality & & & & & & & & & & $\begin{array}{l}1.002^{* * * *} \\
(.0004)\end{array}$ \\
\hline Overall teacher index & $\begin{array}{l}1.005^{* * * *} \\
(.001)\end{array}$ & $\begin{array}{l}1.005 * * * \\
(.001)\end{array}$ & $\begin{array}{l}1.005 * * * * \\
(.001)\end{array}$ & $\begin{array}{l}1.005 * * * \\
(.001)\end{array}$ & $\begin{array}{l}1.005 * * * \\
(.001)\end{array}$ & $\begin{array}{l}1.005 * * * \\
(.001)\end{array}$ & $\begin{array}{l}1.005 * * * \\
(.001)\end{array}$ & $\begin{array}{l}1.005 * * * \\
(.001)\end{array}$ & $\begin{array}{l}1.005 * * * \\
(.001)\end{array}$ & $\begin{array}{l}1.005^{* * * *} \\
(.001)\end{array}$ \\
\hline
\end{tabular}

The goodness of fit test for the full model $(10): F(64,96)=69.42 * * *$
Standard error (Eform) in parentheses. $* * * p<.001, * * p<.05, * p<.01$

\section{Students' Affective Outcome}

Table 3 shows that all three teacher influence indices have a significant positive association with student's affective outcome with a large magnitude of both the teacher quality index and the overall teacher index; $119 \%$ and 112\% respectively (Kyriakides, 2005). Additionally, the most important student's input was their likelihood of applying to university, where students who were very or fairly likely to apply to university were likely to have higher attitude by almost $119 \%$ and $107 \%$ respectively compared to those who are not likely at all to apply to university. Similarly, their academic self-schema had also a significant positive impact on their attitude towards school (Chowdry, Crawford, \& Goodman, 2011).

The school quality effect in Table 4 shows that only three indices were found to have a significant association with student's affective outcome. Specifically, school achievement and standards (AS), quality of provision (QP) and leadership and management (LM) (Murdoch and Phelps, 1973). Also, the school quality of provision and its leadership and management are likely to improve students' attitude towards school, where one would expect students to better value the time they spend at school as long as the school provides better environment for students to be willing to attend school and devote more effort for school work (Kyriakides, 2005; Opdenakker \& Van Damme, 2000). Besides such positive sign, it was moderate reflecting a range of $18 \%$ and 15\% (AS and LM respectively) and 21\% (QP) improvement in student's attitude with each 1 standard deviation increase in those school quality indices.

There is some evidence in the literature that schools which are among the most effective in enhancing cognitive outcomes are not necessarily among the most effective in helping their students achieve non-cognitive outcomes (Kyriakides, 2005; Opdenakker \& Van Damme, 2000).

\footnotetext{
${ }^{3} R^{2}$ was not be reported since the estimation is based on a survey designed dataset, where cases are not independent and so estimating $R^{2}$ would not be appropriate.
} 
The overall teacher index in the full model (10) indicates a positive significant impact of $109 \%$ on attitude. This implies that the teacher effect on attitude was not affected by the overall school quality and that such effect is the leading school process factor that could significantly explain such attitude as has also been observed in the teacher effect models earlier.

Table 3

Teacher Influence on Affective Outcome

\begin{tabular}{|c|c|c|c|}
\hline & (1) & (2) & (3) \\
\hline VARIABLES & OR & OR & OR \\
\hline \multicolumn{4}{|l|}{ Teacher Influence } \\
\hline Student/teacher relation index & $\begin{array}{l}1.05 * * * \\
(0.01)\end{array}$ & & \\
\hline Teacher quality index & & $\begin{array}{l}1.09 * * * \\
(.008)\end{array}$ & \\
\hline Overall teacher index & & & $\begin{array}{l}1.06 * * * \\
(.006)\end{array}$ \\
\hline \multicolumn{4}{|l|}{ Student Inputs } \\
\hline KS3 score $(Z)$ & $\begin{array}{l}1.40^{* * *} \\
(.14)\end{array}$ & $\begin{array}{l}1.25^{* *} \\
(.13)\end{array}$ & $\begin{array}{l}1.34 * * * \\
(.14)\end{array}$ \\
\hline $\begin{array}{l}\text { Likelihood of the young person } \\
\text { level: not at all likely) }\end{array}$ & & & \\
\hline Not very likely & $\begin{array}{l}2.05^{* *} \\
(.59)\end{array}$ & $\begin{array}{l}2.07 * * * \\
(.55)\end{array}$ & $\begin{array}{l}1.86^{* *} \\
(.53)\end{array}$ \\
\hline Fairly likely & $\begin{array}{l}2.63 * * * \\
(.73)\end{array}$ & $\begin{array}{l}2.27 * * * \\
(.62)\end{array}$ & $\begin{array}{l}2.06 * * \\
(.58)\end{array}$ \\
\hline Very likely & $\begin{array}{l}2.97 * * * \\
(.90)\end{array}$ & $\begin{array}{l}2.35^{* * * *} \\
(.70)\end{array}$ & $\begin{array}{l}2.19 * * \\
(.67)\end{array}$ \\
\hline
\end{tabular}

Standard error (Eform) in parentheses. $* * * p<.001, * * p<.05, * p<.01$

Table 4

School Quality Effect on Affective Outcome

\begin{tabular}{|c|c|c|c|c|c|c|c|c|c|c|}
\hline & (1) & (2) & (3) & (4) & (5) & (6) & (7) & (8) & (9) & (10) \\
\hline VARIABLES & OR & OR & OR & OR & OR & OR & OR & OR & OR & OR \\
\hline \multicolumn{11}{|l|}{ School Process } \\
\hline SchOE_A & $\begin{array}{l}1.01 \\
(.01)\end{array}$ & & & & & & & & & \\
\hline SchAS_A & & $\begin{array}{c}1.03 * * \\
(.01)\end{array}$ & & & & & & & & \\
\hline SchPDW_A & & & $\begin{array}{l}1.007 \\
(.009)\end{array}$ & & & & & & & \\
\hline SchQP_A & & & & $\begin{array}{c}1.04 * * \\
(.01)\end{array}$ & & & & & & \\
\hline SchLM_A & & & & & $\begin{array}{l}1.02^{*} \\
(.01)\end{array}$ & & & & & \\
\hline SchESELH_A & & & & & & $\begin{array}{l}.96 \\
(.02)\end{array}$ & & & & \\
\hline SchEPELS_A & & & & & & & $\begin{array}{l}.97 \\
(.02)\end{array}$ & & & \\
\hline SchELMPC_A & & & & & & & & $\begin{array}{c}.95 \\
(.03)\end{array}$ & & \\
\hline SchESELEW_A & & & & & & & & & $\begin{array}{c}.99 \\
(.03)\end{array}$ & \\
\hline Overall school quality & & & & & & & & & & $\begin{array}{l}1.003 \\
(.002)\end{array}$ \\
\hline Overall teacher index & $\begin{array}{c}1.06^{* * * *} \\
(.006)\end{array}$ & $\begin{array}{c}1.06^{* * * *} \\
(.006)\end{array}$ & $\begin{array}{c}1.06^{* * * *} \\
(.006)\end{array}$ & $\begin{array}{c}1.06 * * * \\
(.006)\end{array}$ & $\begin{array}{c}1.06^{* * * *} \\
(.006)\end{array}$ & $\begin{array}{c}1.06 * * * * \\
(.006)\end{array}$ & $\begin{array}{c}1.06^{* * * *} \\
(.006)\end{array}$ & $\begin{array}{c}1.06^{* * * *} \\
(.006)\end{array}$ & $\begin{array}{c}1.06^{* * * *} \\
(.006)\end{array}$ & $\begin{array}{c}1.06 * * * \\
(.006)\end{array}$ \\
\hline
\end{tabular}

The goodness of fit test for the full model $(10): F(64,91)=12.10^{* * *}$

Standard error (Eform) in parentheses. $* * * p<.001, * * p<.05, * p<.01$. 


\section{Conclusion and Discussion}

This paper introduced the school organizational process component of the CIPO model to the educational production function approach by examining the effect of school process inputs on English students' educational cognitive and affective outcomes controlling for both school context and student's inputs.

The primary implication of the findings is that teachers matter. Teachers play a significant positive moderate role in improving student's cognitive outcome and a much bigger role in improving their affective outcome. Additionally, comparing teacher effect with the overall school quality effect, it was found that the first was slightly smaller than the latter when it comes to cognitive outcome, while it was much bigger in the case of affective outcome. Such findings were coupled with another indicating that student's inputs may play a bigger role in explaining their outcomes.

The findings do not necessarily imply that the school does not matter. Rather they imply that teachers within school play a major role in affecting both students' cognitive and affective outcome. Accordingly, both schools and teachers should invest more in teachers' non-financial and/or human qualities, such as teacher effectiveness in monitoring students' performance in terms of homework doing and their availability for student support outside class. Also, schools should pay more attention and put more emphasis on the teacher performance in terms of how he/she influences students' social conduct and how far he/she is being fair with students from different cultural backgrounds. Perhaps, a common proposed policy would be to link teachers' compensation with their performance in terms of the aforementioned aspects rather than just their education and level of experience.

Most school quality aspects were found to have positive significant association with student's cognitive outcome but not necessarily their affective outcome. However, their magnitudes were moderate for the cognitive outcome and bigger for the affective outcome. Moreover, the findings have shown that the school achievement and standards (AS), the quality of provision (QP), and its leadership and management (LM) had positive significant contributions in explaining both outcomes.

The findings of this paper show insignificance of the majority of family background factors, which could suggest in line with what has been reported in the literature regarding the case of England that teacher quality (Slater, Davies, \& Burgess, 2009) and school quality do matter for the cognitive and affective outcomes of students.

The findings have shown that student's attitude towards school or put differently their perception of the school was significantly positively related to the overall academic achievement of the school, which would make both parents and the children somehow equally happy when making the decision of which school to join. Accordingly, parents should not form their decision entirely based on just the level of academic achievement of the school but also on other factors such as the quality of how effective will teaching and learning be in meeting the full range of their children's needs, how well do the curriculum and other activities meet the range of needs and interests of the children and how well their children are going to be cared for, guided and supported.

Although the analysis has adopted the CIPO model to control for the full dimensionality of the educational process, a clear limitation exists with the lack of evidence about the effect of school 
resources inputs, which comes as a result of the lack of the necessary data about school related expenditure indicators. It would be important for future research to examine the overall teacher index combining both observable teacher inputs about their level of education, experience and salary with the student's perception of their teacher so that a clearer conclusion could be drawn about the full nature of the teacher effect. Another limitation of the analysis is that it lacked information on the classroom level restricting the implementation of multilevel analysis.

\section{References}

Aaronson, D., Barrow, L., \& Sander, W. (2007). Teachers and student achievement in the Chicago public high schools. Journal of Labor Economics, 25(1), 95-136.

Administrative Data Liaison Service (2010). National Pupil Database. Retrieved from http://adls.ac.uk/department-foreducation/dcsf-npd/?detail [accessed 05 September 2014].

Anderson, C. S. (1982). The search for school climate: A review of the research. Review of Educational Research, 52(3), 368420.

Angrist, J. D., \& Lavy, V. (2001). Does teacher training affect pupil learning? Evidence from matched comparisons in Jerusalem public schools. Journal of Labor Economics, 19(2), 343-369.

Armor, D., Conry-Oseguera, P., Cox, M., King, N. J., Mcdonnell, L., Pascal, A., Edward, W. Pauly, \& Zellman, G. (1976). Analysis of the reading program in selected Los Angeles minority schools. Santa Monica: Rand.

Bellei, C. (2009). Does lengthening the school day increase students' academic achievement? Results from a natural experiment in Chile. Economics of Education Review, 28, 629-640.

Chowdry, H., Crawford, C., \& Goodman, A. (2009). Drivers and barriers to educational success evidence from the longitudinal study of young people in England. London: Department for Children, Schools and Families.

Chowdry, H., Crawford, C., \& Goodman, A. (2011). The role of attitudes and behaviours in explaining socio-economic differences in attainment at age 16. Longitudinal and Life Course Studies, 2(1), 59-76

Chowdry, H., Gregg, P. A., Goodman, A., Crawford, C., Dearden, L., Joyce, R., Sibieta, L., Sylva, K., \& Washbrook, E. V. (2010). Poorer children's educational attainment: how important are attitudes and behaviour? York: Joseph Rowntree Foundation.

Coleman, J. S. (1966). Equality of educational opportunity. Washington, DC: Government Printing Office.

Cronbach, L. J. (1951). Coefficient alpha and the internal structure of tests. Psychometrika, 16(3), 297-334.

Daly, P. (1991). How large are secondary school effects in Northern Ireland? School Effectiveness and School Improvement, 2(4), 305-323.

Das, J., Dercon, S., Habyarimana, J., \& Krishnan, P. (2007). Teacher shocks and student learning evidence from Zambia. Journal of Human Resources, 42(4), 820-862.

Duran, B. J., \& Weffer, R. E. (1992). Immigrants' aspirations, high school process, and academic outcomes. American Educational Research Journal, 29(1), 163-181.

Edmonds, R. (1979). Effective schools for the urban poor. Educational Leadership, 37(1), 15-27.

Faguet, J., \& Sanchez, F. (2008). Decentralization's effects on educational outcomes in Bolivia and Colombia. World Development, 36(7), 1294-1316.

Galiani, S., Gertler, P., \& Schargrodsky, E. (2008). School decentralization: Helping the good get better, but leaving the poor behind. Journal of Public Economics, 92, 2106-2120.

Galiani, S., \& Perez-Truglia, R. (2011). School management in developing countries. Paper presented at Education Policy in Developing Countries: What Do We Know, and What Should We Do to Understand What We Don't Know? February 4-5, University of Minnesota.

Glewwe, P. W., Hanushek, E. A., Humpage, S. D., \& Ravina, R. (2011). School resources and educational outcomes in developing countries: a review of the literature from 1990 to 2010. Working Paper No.17554, Massachusetts: National Bureau of Economic Research. 
Glick, P., \& Sahn, D. E. (2010). Early academic performance, grade repetition, and school attainment in Senegal: A panel data analysis. The World Bank Economic Review, 24(1), 93-120.

Hanushek, E.A. (1971). Teacher characteristics and gains in student achievement: Estimation using micro-data. American Economic Review, 61 (2), pp.280-288.

Hanushek, E. A. (1981). Throwing money at schools. Journal of Policy Analysis and Management, 1(1), 19-41.

Hanushek, E. A. (1986). The economics of schooling: Production and efficiency in public schools. Journal of Economic Literature, $24,1141-1177$.

Hanushek, E., \& Luque, J. (2003). Efficiency and equity in schools around the world. Economics of Education Review, 22(5), 481-502.

Hedges, L.V., Laine, R. D., \& Greenwald, R. (1994a). When reinventing the wheel is not necessary: A case study in the use of meta-analysis in education finance. Journal of Education Finance, 20(1),1-20.

Jimenez, E., \& Sawada, Y. (1999). Do community-managed schools work? An evaluation of El Salvador's EDUCO program. World Bank Economic Review, 13(3), 415-441.

Jimenez, E., \& Sawada, Y. (2003). Does community management help keep kids in schools? Evidence using panel data from El Salvador's EDUCO Program. CIRJE F-Series CIRJE-F-236, CIRJE, Faculty of Economics, University of Tokyo.

Kerckhoff, A. C. (1986). Effects of ability grouping in British secondary schools. American Sociological Review, 51(6), 842-858.

Knoeppel, R. C., Verstegen, D. A., \& Rinehart, J. S. (2007). what is the relationship between resources and student achievement? A canonical analysis. Journal of Education Finance, 33(2), 183-202.

Knuver, A. W. M., \& Brandsma, H. P. (1993). Cognitive and affective outcomes in school effectiveness research. School effectiveness and school improvement, 4(3), 189-204.

Kyriakides, L. (2005). extending the comprehensive model of educational effectiveness by an empirical investigation. School Effectiveness and School Improvement, 16(2), 103-152.

Levaččićć, R., \& Vignoles, A. (2002). Researching the links between school resources and student outcomes in the UK: A review of issues and evidence. Education Economics, 10(3), 313-331.

Link, C. R., \& Ratledge, E. C. (1979). Student perceptions, IQ, and achievement. The Journal of Human Resources, 14(1), 98111.

Madeira, R. (2012). The effects of decentralization on schooling: evidence from the sao paulo state education reform. Working Paper n⿳0 2012-26, Department of economics, fea-usp.

Menezes-Filho, N., \& Pazello, E. (2007). Do teachers' wages matter for proficiency? Evidence from a funding reform in Brazil. Economics of Education Review, 26, 660-672.

Mortimore, P. (1993). School effectiveness and the management of effective learning and teaching. School Effectiveness and School Improvement, 4(4), 290-310.

Mortimore, P., Sammons, P., Stoll, L., Lewis, D., \& Ecob, R. (1988). School matters: the junior years. Wells, UK: Open Books.

Murnane, R. J. (1975). The impact of school resources on the learning of inner city children. Cambridge, MA: Ballinger Publishing Co.

Opdenakker, M. C., \& Van Damme, J. (2000). Effects of schools, teaching staff and classes on achievement and well-being in secondary education: Similarities and differences between school outcomes. School Effectiveness and School Improvement, $11(2), 165-196$.

PISA (2009). PISA 2009 Results. What Makes a School Succesful? Resources, Policies and Practices. Volume IV. Organisation for Economic Co-operation and Development.

Reynolds, D. (1982). The search for effective schools. School Organisation, 2(3), 215-237.

Rivkin, S. G., Hanushek, E. A., \& Kain, J. F. (2005). Teachers, schools, and academic achievement. Econometrica, 73(2), 417458.

Rutter, M. (1979). Fifteen thousand hours: Secondary schools and their effects on children. Somerset, UK: Open Books.

Sammons, P., Hillman, J., \& Mortimore, P. (1995). Key characteristics of effective schools: A review of school effectiveness research. London: OFSTED. 
Sammons, P., Nuttall, D., Cuttance, P., \& Thomas, S. (1995). Continuity of school effects: A longitudinal analysis of primary and secondary school effects on GCSE performance. School Effectiveness and School Improvement, 6(4), 285-307.

Scheerens, J., \& Creemers, B. P. M. (1996). School effectiveness in the Netherlands; the modest influence of a research programme. School Effectiveness and School Improvement, 7(2), 181-195.

Slater, H., Davies, N., \& Burgess, S. (2009). Do teachers matter? Measuring the variation in teacher effectiveness in England. Working paper No.09/212. Bristol: Centre for Market and Public Organisation.

Stalling, J. (1975). Implementation and child effects of teaching practices in follow through classrooms. Monographs of the Society for Research in Child Development, 40(7/8), 1-133.

Summers, A. A., \& Wolfe, B. L. (1977). Do schools make a difference? American Economic Review, 67(4), 639-652.

Teddlie, C. (1994). The integration of classroom and school process data in school effectiveness research. In D. Reynolds, B. P. M. Creemers, P. S. Nesselrodt, E. C. Schaffer, S. Stringfield, \& C. Teddlie (Eds.), Advances in school effectiveness research and practice (pp. 111-132). Oxford: Pergamon.

Teddlie, C., \& Reynolds, D. (2000). The international handbook of school effectiveness research. London: Routledge Falmer.

Tymms, P. (1992). The relative effectiveness of post-16 institutions in England (including Assisted Places Scheme Schools). British Educational Research Journal, 18(2), 175-192.

Walberg, H. J. (1984). Improving the productivity of American schools. Educational Leadership, 41(8), 19-27.

Weber, G. (1971). Inner city children can be taught to read: Four successful schools. Washington, DC: Council for Basic Education, occasional papers Number 18.

Wilkins, J. D., \& Raudenbush, S. W. (1989). A longitudinal hierarchical linear model for estimating school effects and their stability. Journal of Educational Measurement, 26(3), 209-232.

Winkler, D. R. (1975). Educational achievement and school peer group composition. Journal of Human Resources, 10(2), 189205.

Woessmann, L. (2003). Schooling resources, educational institutions, and student performance: The international evidence. Oxford Bulletin of Economics and Statistics, 65(2), 117-170.

http://www.hmc.org.uk/about-hmc/projects/the-british-education-system/ 